\title{
Adolescent learning support: relationship with burnout and achievement
}

\begin{abstract}
This study primarily aimed to determine the effects of burnout as an intermediary link between student achievement and learning support on boys and girls and to ascertain the direct and indirect effects of learning support on student achievement. Study participants were adolescents aged 12 to 17 years (male $\mathrm{N}=1170$ and female $\mathrm{N}=1189$ ). Results indicated that both models produced between boys and girls were equal. Burnout emerged as an intermediary link between student achievement and learning support. Exhaustion and inadequacy of male students exhibited a significant relationship between the intermediary support of teachers, peers, and parents. The inadequacy of female students was also a significant intermediary. In terms of the direct effect, peer support significantly contributed to the student achievement of boys and girls. Moreover, burnout influenced student achievement. Based on the findings, this study recommended that the students must be taught to adapt themselves to teaching, learning, and academic achievement, thereby improve engagement and reduce burnout.
\end{abstract}

Keyword: Achievement; Adolescent; Burnout; Gender; Learning support 